\title{
Article \\ Effect of GSTA1 Variants on Busulfan-Based Conditioning Regimen Prior to Allogenic Hematopoietic Stem-Cell Transplantation in Pediatric Asians
}

\author{
Ai-Hoc Nguyen 1,2 (D), Mohitosh Biswas 1,2,3 ${ }^{\mathbb{D}}$, Apichaya Puangpetch 1,2 ${ }^{\mathbb{D}}$, Santirhat Prommas ${ }^{1,2}$, \\ Samart Pakakasama 4 , Usanarat Anurathapan 4 (D), Jiratha Rachanakul ${ }^{1,2}$, Rattanaporn Sukprasong 1,2(D), \\ Nutthan Nuntharadtanaphong ${ }^{1,2}$, Nutcha Jongjitsook ${ }^{1,2}$, Suradej Hongeng ${ }^{(\mathbb{D})}$ and Chonlaphat Sukasem ${ }^{1,2,5,6, * \mathbb{D}}$
}

\section{check for}

updates

Citation: Nguyen, A.-H.; Biswas, M.; Puangpetch, A.; Prommas, S.; Pakakasama, S.; Anurathapan, U.; Rachanakul, J.; Sukprasong, R.; Nuntharadtanaphong, N.; Jongjitsook, N.; et al. Effect of GSTA1 Variants on Busulfan-Based Conditioning Regimen Prior to Allogenic Hematopoietic Stem-Cell Transplantation in Pediatric Asians. Pharmaceutics 2022, 14, 401.

https://doi.org/10.3390/

pharmaceutics14020401

Academic Editors: Francisco Abad Santos, Pablo Zubiaur and Pedro Dorado

Received: 9 December 2021 Accepted: 7 February 2022 Published: 11 February 2022

Publisher's Note: MDPI stays neutral with regard to jurisdictional claims in published maps and institutional affiliations.

Copyright: (C) 2022 by the authors. Licensee MDPI, Basel, Switzerland. This article is an open access article distributed under the terms and conditions of the Creative Commons Attribution (CC BY) license (https:// creativecommons.org/licenses/by/ $4.0 /)$.
1 Division of Pharmacogenomics and Personalized Medicine, Department of Pathology, Faculty of Medicine Ramathibodi Hospital, Mahidol University, Bangkok 10400, Thailand; aihoc050994@gmail.com (A.-H.N.); biswas_07pharm@ru.ac.bd (M.B.); apichaya.pua@mahidol.ac.th (A.P.); santirhat.pro@mahidol.ac.th (S.P.); jiratha.rac@mahidol.edu (J.R.); rattanaporn.suk@mahidol.ac.th (R.S.); nutthan.nun@mahidol.ac.th (N.N.); pearnutcha_1997@hotmail.com (N.J.)

2 Laboratory for Pharmacogenomics, Somdech Phra Debaratana Medical Center (SDMC), Ramathibodi Hospital, Bangkok 10400, Thailand

3 Department of Pharmacy, Faculty of Science, University of Rajshahi, Rajshahi 6205, Bangladesh

4 Division of Hematology-Oncology, Department of Pediatrics, Faculty of Medicine Ramathibodi Hospital, Mahidol University, Bangkok 10400, Thailand; samart.pak@mahidol.ac.th (S.P.); usanarat.anu@mahidol.ac.th (U.A.); suradej.hon@mahidol.ac.th (S.H.)

5 Division of Pharmacogenomics and Precision Medicine, The Preventive Genomics \& Family Check-Up Services Center, Bumrungrad International Hospital, Bangkok 10400, Thailand

6 MRC Centre for Drug Safety Science, Department of Pharmacology and Therapeutics, Institute of Systems, Molecular and Integrative Biology, University of Liverpool, Liverpool L69 3GL, UK

* Correspondence: chonlaphat.suk@mahidol.ac.th

\begin{abstract}
Busulfan is widely used as a chemotherapy treatment before hematopoietic stem-cell transplantation (HSCT). However, the response of busulfan is highly variable and unpredictable, whereby the pharmacogenetic interference of glutathione $S$-transferase (GST) has strong evidence in Caucasians and some adult Asians but not in pediatric Asian patients. This study was aimed at investigating the associations of GST genetic polymorphisms with variations in the pharmacokinetic (PK) properties of busulfan in pediatric Asian patients. This retrospective cohort study recruited 92 pediatric patients. The polymorphism of GSTA1 was genotyped by Sanger sequencing, and GSTM1 and GSTP1 were genotyped by real-time PCR. Drug concentration and PK estimation were identified using an LC-MS/MS method and a noncompartmental model. Statistical analysis was performed by R software. Out of 92 patients, 48 (53\%) were males, the mean age was $8.4 \pm 5.12$ years old, and the average weight was $26.52 \pm 14.75 \mathrm{~kg}$. The allele frequencies of GSTA1*B and of GSTM1 and GSTP1* deletions were $16.9 \%, 68.5 \%$, and $21.2 \%$, respectively. Patients with GSTA1*B had a statistically significant impact on the PK of busulfan, whereas those with GSTM1 and GSTP1 did not $(p>0.05)$. The carriers of $G S T A 1^{*} B$ showed a significant difference compared to noncarriers in terms of $\mathrm{t}_{1 / 2}$ (for first dose: 161.9 vs. $134.3 \mathrm{~min}, p=0.0016$; for second dose: 156.1 vs. $129.8, p=0.012$ ), CL (88.74 vs. $124.23 \mathrm{~mL} / \mathrm{min}, p=0.0089), \mathrm{C}_{\max }(4232.6$ vs. $3675.5 \mathrm{ng} / \mathrm{mL}, p=0.0021)$, and AUC (5310.6 vs. $4177.1 \mu \mathrm{M} / \mathrm{min}, p=0.00033)$. The augmentation of AUC was around $27.1 \%$ in patients carrying the GSTA1*B variant. The GSTA1 polymorphism was significantly associated with variations of the pharmacokinetic properties of busulfan treatment in pediatric Asian patients.
\end{abstract}

Keywords: busulfan; hematopoietic stem-cell transplantation pharmacokinetics; GST genetic polymorphisms; pediatric Asians 


\section{Introduction}

Busulfan is a bifunctional alkylating agent, widely used as chemotherapy treatment before hematopoietic stem-cell transplantation (HSCT). High exposure of busulfan is needed to destroy cancer cells, but it can also destroy normal hematopoietic cells. Subsequently, HSCT is used to "rescue" the patients from the side effects of chemotherapy [1]. Busulfan serves not only as a cornerstone for the success of this process, but also as a replacement for total body irradiation (TBI) of the conditioning regimen before HSCT [2-4].

The variation of busulfan's response is highly unpredictable in terms of both pharmacokinetic (PK) and pharmacodynamic (PD) aspects. Exceeding the therapeutic range can cause graft-versus-host disease (GvHD), sinusoidal obstruction syndrome (SOS), and lower overall survival [5,6]. Going below the therapeutic range can cause graft failure and disease relapse [7]. Many attempts have been made to take into account the potential influencing factors, such as gender, age, weight, metabolism pathway and genetic profile. Unfortunately, the prediction of busulfan exposure still remains unachievable. Moreover, pediatric Asian patients are usually considered the most vulnerable patients in need due to the metabolism's immaturity and the increasing incidence of toxicity in children [8,9], as well as the low minor allele frequency in Asians. This scarcity creates a burden on the patient's clinical treatment, as well as on conducting proper genetic investigations in the Asian population compared to the Caucasian population $[10,11]$.

There have been many studies on the metabolism of busulfan. Some studies proposed the involvement of glutathione S-transferase (GST) [12], whereas others indicated the involvement of cytochrome P450 (CYP) enzymes, such as CYP2B6 and CYP39A1 [13-15]. Unlike GST, clear biological evidence of the involvement of CYP enzymes is still absent; thus, busulfan cannot be considered their substrate. Furthermore, CYP enzymes are believed to participate in the formation of sulfolane, a metabolite of $\mathrm{Bu}$, in the downstream oxidation period, but not the active parent molecule [12,13]. At our current level of knowledge, GST is believed to be a direct and the most predominant metabolizer of busulfan.

GST, an enzyme of phase II metabolism in liver cells encoded by the GST gene, has successfully been isolated in eight subfamilies [16], among which GSTA1, GSTM1, and GSTP1 are the most paramount. In an vitro study, Czerwinski et al. [17] extracted GST enzymes from the liver cells of a female Caucasian donor and revealed that the activities of GSTM1 and GSTP1 enzymes are equal to around $46 \%$ and $18 \%$ of that of the GSTA1 enzyme, respectively. The polymorphism of GSTA1 essentially occurs in the promotor region. The variants of three linkage disequilibrium loci (567T > G, 69C > T, 52G > A) weaken the binding force of the Sp1 transcription factor on the promotor region and decrease the expression of the GSTA1 enzyme [18]. The whole-gene deletion of GSTM1 and the nonsynonymous variant at locus 313A > G of GSTP1 can synthesize dysfunctional enzymes or completely prevent synthesis. These genetic impacts have been examined in Caucasians $[19,20]$ and some adult Asians [10,21]. Pediatric Asians were also investigated by some authors [22] but the results remained negative, in contrast to Israelis [23]. The Israeli population is geographically considered Asian but their GSTA1 genetic profile is more similar to Caucasians [23]. The reasons for this phenomenon in Asians may be due to the low minor allele frequency [22], which results in a burden on the sample size for investigation in Asians, and which may be due to the metabolism's immaturity in children, causing greater fluctuation in their PK behaviors.

In consideration of the abovementioned drawbacks, this study was aimed at investigating the potential impact of GSTA1, GSTM1 and GSTP1 genetic polymorphisms on the PK properties of busulfan in pediatric Asian patients.

\section{Patients and Methods}

\subsection{Patients and Conditioning Regimens}

In this retrospective cohort study, we recruited 92 pediatric patients who underwent haploidentical HSCT in the PPM Laboratory, Ramathibodi Hospital, Mahidol Uni- 
versity from September 2015 to September 2020. Before HSCT, patients received IV busulfan (Busulfex, Otsuka America Pharmaceutical, Rockville, MD, USA) once daily for 4 days. The first dose was personalized on the basis of body surface area (BSA) and age. Children $<2$ years old, 2-6 years old and $>6$ years old were administered 80, 120 and $130 \mathrm{mg} / \mathrm{m}^{2} /$ day of busulfan, respectively. Therapeutic drug monitoring (TDM) was performed to adjust dosages until the target range was attained on subsequent days. The Medical Ethics Committee of Ramathibodi hospital, Mahidol University approved the study (protocol code ID 04-61-37 and date of approval 12 June 2018). All patients and/or parents provided informed consent in accordance with the Helsinki Declaration.

\subsection{Conditioning-Related Regimen and Prophylaxis of Infection}

These regimens were covered before and after transplantation. During busulfan administration, patients were also prescribed ranitidine for gastroprotection, phenytoin for anti-epilepsy, and ciprofloxacin, penicillin $\mathrm{V}$ and acyclovir for prophylaxis of infection. Furthermore, fludarabine was administered $1 \mathrm{~h}$ before busulfan as part of the conditioning regimen.

\subsection{DNA Extraction and GST Genotyping}

Pretransplant genomic DNA was extracted using magnetic bead technology, which was executed by MagNA Pure Compact nucleic acid purification kit and MagNA Pure Compact Instrument (Roche Diagnostics Ltd. ${ }^{\circledR}$, Indianapolis, IN, USA). The extracted DNA was then quantified by a NanoDrop Spectrophotometer (Thermo Scientific ${ }^{\circledR}$, Waltham, MA, USA) at wavelength of 230, 260 and $280 \mathrm{~nm}$. An extracted DNA concentration higher than $50 \mathrm{ng} / \mu \mathrm{L}$ is typically considered qualified enough. The TaqMan allelic discrimination method (Applied Biosystem ${ }^{\circledR}$, Foster City, CA, USA) was used for the detection of the GSTP1 gene (c.A313G; rs1695; pI105V), single-nucleotide polymorphisms (SNPs), and GSTM1 copy number variations, as previously described [24]. The GSTM1 and GSTP1 genes were amplified by TaqMan genotyping assay (Applied Biosystems ${ }^{\circledR}$, Waltham, MA, USA). Their catalog numbers are Hs02575461_cn and C__3237198_20, respectively. All real-time PCR plates were prepared as per the instructions of manufacturers and run inside a real-time PCR system Viia 7 (Life Technology ${ }^{\circledR}$, Foster City, CA, USA). The operating software of real-time PCR system is QuantStudio version 1.3 (Applied Biosystems ${ }^{\circledR}$, MA, USA). For GSTM1, Copy Caller Software version 2.1 (Applied Biosystems ${ }^{\circledR}$, MA, USA) was additionally used to identify CNVs. In addition, Sanger sequencing (Applied Biosystems $\left.{ }^{\circledR}, \mathrm{MA}, \mathrm{USA}\right)$ was performed as a genotyping service (U2Bio ${ }^{\circledR}$, Bangkok, Thailand) to investigate the promoter region of GSTA1 that defines ${ }^{*} A$ and ${ }^{*} B$ alleles $\left(69 \mathrm{C},-52 \mathrm{G}\right.$, designated as $G S T A 1^{*} A$; $-69 \mathrm{~T}$, $-52 \mathrm{~A}$, designated as $\left.G S T A 1^{*} B\right)$. Due to the distance between the two SNPs, C-69T (rs3957357) and G-52A (rs3957356), being very short (just 17 nucleotides), Sanger sequencing was the optimal method for their detection and determination of linkage disequilibrium in the Thai population. The promoter region of GSTA1 gene was amplified with the forward primer GSTA1-F (5'-ACT TTG ATT GCC AAC CTT GAA- $\left.3^{\prime}\right)$ and the reverse primer GSTA1-R (5'-TTA AAC GCT GTC ACC GTC CT- $\left.3^{\prime}\right)$. The referring primers were commercially provided by manufacturer (Thermo Scientific ${ }^{\circledR}$, MA, USA) and they worked follow the thermal program: $72^{\circ} \mathrm{C}$ in $10 \mathrm{~min}$, then 40 cycles of temperature $\left(96{ }^{\circ} \mathrm{C}\right.$ in $10 \mathrm{~s}, 61{ }^{\circ} \mathrm{C}$ in $15 \mathrm{~s}, 72{ }^{\circ} \mathrm{C}$ in $\left.20 \mathrm{~s}\right)$, and finally $72{ }^{\circ} \mathrm{C}$ in $10 \mathrm{~min}$.

\subsection{Pharmacokinetic Analysis}

The TDM results of the first dose and second dose were used to evaluate the genetic impact. Blood samples were collected from peripheral veins to avoid contamination with IV busulfan in the central venous catheter. The selected timepoints were 0,180 , 195, 210, 240, 300, 360 and $480 \mathrm{~min}$. Blood samples were maintained in EDTA at $4{ }^{\circ} \mathrm{C}$ before being quantified. Busulfan determination and validation was performed by an LC system (Agilent Technologies ${ }^{\circledR}$, Santa Clara, CA, USA) and by a detector MS/MS (AB Sciex ${ }^{\circledR}$, Vaughan, ON, Canada), as described elsewhere [25] with minor modifications. Internal standard (IS) is busulfan-d8 (CDN Isotopes ${ }^{\circledR}$, Pointe-Claire, QC, Canada). Before 
being injected to the LC-MS/MS system, busulfan was extracted by Solid Phase Extraction (SPE) cartridges (Waters ${ }^{\circledR}$, MA, USA). Briefly described, $520 \mu \mathrm{L}$ sample $(200 \mu \mathrm{L}$ plasma sample, $20 \mu \mathrm{L}$ IS and $300 \mu \mathrm{L}$ deionized water) was loaded on SPE instrument (Waters ${ }^{\circledR}$, Milford, MA, USA). Busulfan was then retrieved from SPE cartridges by methanol (RCI Labscan $^{\circledR}$, Bangkok, Thailand) and injected into LC-MS/MS system. The retention time of busulfan and IS were around 5 and $5.15 \mathrm{~min}$, respectively. Each patch run had quality control at 3 concentrations $(600,2700,4800 \mathrm{ng} / \mathrm{mL})$. Linear range was from 200 to $6000 \mathrm{ng} / \mathrm{mL}$, built from 7-point calibration. Linear regression constant $\left(\mathrm{R}^{2}\right)$ was higher than 0.999 in all validated batches. The accuracy and precision of the lowest point $(200 \mathrm{ng} / \mathrm{mL})$ was varied within $\pm 20 \%$. The accuracy and precision of 6 other points was varied within $\pm 15 \%$. PK analysis was performed using the noncompartmental model of PKanalix version 2020R1 (Lixoft ${ }^{\circledR}$, Paris, France). The following PK parameters were estimated: half-life $\left(t_{1 / 2}\right)$, clearance $(C L)$, highest concentration $\left(C_{\max }\right)$, volume of distribution $(V d)$, and area under the concentration-time curve (AUC).

\subsection{Statistical Analysis}

$t$-tests and ANOVA tests were employed to evaluate the PK differences where appropriate. All analyses and data visualization were performed by R software version 4.0.2 ( $R$ Foundation for Statistical Computing, Vienna, Austria). Results were considered significant at $p<0.05$.

\section{Results}

\subsection{Patient Characteristics}

Table 1 summarizes the demographic information of the 92 patients. Their mean age was $8.4 \pm 5.12$ years old, and their mean weight was $26.52 \pm 14.75 \mathrm{~kg}$. Out of 92, 40 patients had thalassemia. All patients received IV busulfan once daily prior to haploidentical hematopoietic stem-cell transplantation. All patients received phenytoin as part of their anti-seizure regimen. Fludarabine was administered concomitantly with busulfan in 72 patients. The PK differences were not statistically significant between thalassemia and non-thalassemia patients, nor between patients with and without fludarabine.

\subsection{Overview of Genetic Influences on PK of Busulfan}

Table 3 provides an overview of the associations of GST genetic polymorphisms with each PK parameter. These differences were seen more clearly in the first dose than in the second dose. In both doses, statistically significant differences in PK parameters were observed in patients with GSTA1*B, but not in patients with GSTP1*A and the GSTM1 deletion. These differences were noted in terms of $t, C L, C_{\max }$ and AUC for the first dose and $t_{1 / 2}$ for the second dose. Compared to noncarriers of the variant GSTA1 ${ }^{*}$, carriers of it had a higher $\mathrm{t}_{1 / 2}$ (for first dose-161.9 vs. $134.3 \mathrm{~min}, p=0.0016$; for second dose -156.1 vs. $129.8, p=0.012)$, lower CL (88.74 vs. $124.23 \mathrm{~mL} / \mathrm{min}, p=0.0089)$, higher $C_{\max }(4232.6$ vs. $3675.5 \mathrm{ng} / \mathrm{mL}, p=0.0021)$, and higher AUC (5310.6 vs. $4177.1 \mu \mathrm{M} / \mathrm{min}, p=0.00033)$.

\subsection{The Impact of GSTA1 Polymorphism on PK of Busulfan}

Figure 1 describes the statistically significant impacts of GSTA1 polymorphism on the PK of the first and second doses of busulfan. These impacts were detected more clearly in the first dose than in the second dose. For the analysis of CL of both doses and the analysis of $\mathrm{Vd}$ of the first dose, patients were classified into two groups, wild-type and variant, due to the small sample size. For other analyses, patients were classified into three groups: homozygous wild-type, heterozygous, and homozygous mutant. In terms of the PK of the first dose (before adjustment), the carriers of variant allele GSTA1* $B$ had a higher half-life, a higher $C_{\max }$, a higher $A U C_{0-i n f}$, a lower $C L$, and a suggestive trend of a lower $\mathrm{Vd}(p=0.071)$. In terms of the PK of the second dose (after adjustment), GSTA1 created a difference in the half-life, along with a suggestive trend of difference in the CL $(p=0.063)$. 
Table 1. Patient characteristics.

\begin{tabular}{|c|c|c|c|}
\hline Characteristics & & Number of Patients & Percentage \\
\hline \multirow[t]{2}{*}{ Gender } & Male & 48 & $53 \%$ \\
\hline & Female & 44 & $47 \%$ \\
\hline \multirow[t]{15}{*}{ Diagnosis } & Thalassemia & 40 & $43.5 \%$ \\
\hline & Non-thalassemia & 52 & $56.5 \%$ \\
\hline & Neuroblastoma & 9 & $9.9 \%$ \\
\hline & AML & 7 & $7.6 \%$ \\
\hline & ALL & 8 & $8.6 \%$ \\
\hline & CML & 1 & $1.1 \%$ \\
\hline & JMML & 1 & $1.1 \%$ \\
\hline & Metabolic diseases & 3 & $3.3 \%$ \\
\hline & Immunodeficiencies & 14 & $15 \%$ \\
\hline & AIHA & 1 & $1.1 \%$ \\
\hline & MDS & 2 & $2.2 \%$ \\
\hline & SAA & 3 & $3.3 \%$ \\
\hline & Osteopetrosis & 1 & $1.1 \%$ \\
\hline & $\begin{array}{l}\text { Undifferenciated round-cell } \\
\text { tumor }\end{array}$ & 1 & $1.1 \%$ \\
\hline & Other & 1 & $1.1 \%$ \\
\hline \multirow[t]{11}{*}{ Conditioning regimen } & BuCyMesna & 7 & $7.6 \%$ \\
\hline & BuCyATGMesna & 1 & $1.1 \%$ \\
\hline & BuMel & 4 & $4.3 \%$ \\
\hline & BuMelATG & 4 & $4.3 \%$ \\
\hline & BuFluATG & 46 & $49.9 \%$ \\
\hline & BuFluThio & 19 & $20.7 \%$ \\
\hline & BuFluCyATGMesna & 1 & $1.1 \%$ \\
\hline & BuFluMelATG & 3 & $3.3 \%$ \\
\hline & BuFluATGRit & 3 & $3.3 \%$ \\
\hline & BuFluThioRit & 2 & $2.2 \%$ \\
\hline & $\mathrm{Bu}$ and BuCyATG & 2 & $2.2 \%$ \\
\hline \multirow[t]{3}{*}{ Age } & $0-2$ years old & 8 & $8.7 \%$ \\
\hline & 2-6 years old & 27 & $29.3 \%$ \\
\hline & 6-21 years old & 57 & $62 \%$ \\
\hline \multirow[t]{3}{*}{ Age (year) } & Min & 0.42 & \\
\hline & Mean & 8.41 & \\
\hline & Max & 21.59 & \\
\hline \multirow[t]{3}{*}{ BSA (square meters) } & Min & 0.27 & \\
\hline & Mean & 0.935 & \\
\hline & Max & 1.83 & \\
\hline \multirow[t]{3}{*}{ Height (centimeter) } & Min & 53.40 & \\
\hline & Mean & 121.91 & \\
\hline & Max & 175.0 & \\
\hline \multirow[t]{3}{*}{ Weight (kilograms) } & Min & 4.10 & \\
\hline & Mean & 26.52 & \\
\hline & Max & 72.20 & \\
\hline
\end{tabular}

$\overline{\mathrm{AML}}$, acute myeloblastic leukemia; ALL, acute lymphoblastic leukemia; CML, chronic myeloblastic leukemia; JMML: juvenile myelomonocytic leukemia; AIHA, autoimmune hemolytic anemia; MDS, myelodysplastic syndrome; SAA, severe aplastic anemia; Bu, busulfan; Mel, melphalan; Cy, cyclophosphamide; Flu, fludarabine; ATG, anti-thymocyte globulin; Thio, thiotepa; Rix, rituximab; Mesna, 2-mercaptoethane sodium sulfonate.

\subsection{Frequencies of GSTA1, GSTM1 and GSTP1 Genotypes}

The allele frequencies of GSTA1, GSTM1 and GSTP1 are illustrated in Table 2. All detected SNPs were within the Hardy-Weinberg equilibrium $(p>0.05)$. For GSTM1, 
deletions and 1-3 copy number variations (CNVs) were detected, and the tests for HardyWeinberg equilibrium were not performed because our genotyping technique cannot distinguish if an individual with $2 \mathrm{CNVs}$ is homozygous GSTM1* $1 C N V{ }^{*} 1 \mathrm{CNV}$ or heterozygous GSTM1*2CNV/*deletion [26,27]. The frequencies of GSTA1*B, GSTM1*null**null, and GSTP ${ }^{*} G$ were $16.9 \%, 68.5 \%$, and $21.2 \%$, respectively.

Table 2. Distributions of GSTA1, GSTM1 and GSTP1 variants in all patients.

\begin{tabular}{|c|c|c|c|c|}
\hline Gene & & & $N(\%)$ & HWE \\
\hline \multirow{5}{*}{ GSTA1 } & \multirow{3}{*}{ Diplotype } & ${ }^{*} A /{ }^{*} A$ & $67(72.8 \%)$ & \multirow{5}{*}{0.2542} \\
\hline & & ${ }^{*} A /{ }^{*} B$ & $19(20.7 \%)$ & \\
\hline & & ${ }^{*} B /{ }^{*} B$ & $6(6.5 \%)$ & \\
\hline & \multirow{2}{*}{ Haplotype } & ${ }^{*} A$ & $83.1 \%$ & \\
\hline & & ${ }^{*} B$ & $16.9 \%$ & \\
\hline \multirow{5}{*}{ GSTP1 } & \multirow{3}{*}{ Diplotype } & $A / A$ & $55(59.8 \%)$ & \multirow{5}{*}{0.5896} \\
\hline & & $A / G$ & $35(38.0 \%)$ & \\
\hline & & $G / G$ & $2(2.2 \%)$ & \\
\hline & \multirow{2}{*}{ Haplotype } & ${ }^{*} A$ & $78.8 \%$ & \\
\hline & & ${ }^{*} G$ & $21.2 \%$ & \\
\hline \multirow{4}{*}{ GSTM1 } & \multicolumn{2}{|c|}{ Deletion } & $63(68.4 \%)$ & \multirow{4}{*}{ NA } \\
\hline & \multicolumn{2}{|c|}{$C N V: 1$} & $26(28.3 \%)$ & \\
\hline & \multicolumn{2}{|c|}{ CNV:2 } & $2(2.2 \%)$ & \\
\hline & \multicolumn{2}{|c|}{$C N V: 3$} & $1(1.1 \%)$ & \\
\hline
\end{tabular}

For GSTA1, two detected SNPs (G-52 (rs3957656) and C-69T (rs3957657)) were in a full linkage disequilibrium: $\mathrm{CNV} —$ copy number variation; NA—not applicable; HWE—Hardy-Weinberg equilibirum.

Table 3. Differences between pharmacokinetic parameters of $\mathrm{Bu}$ and genetic polymorphisms ( $t$-test or ANOVA).

\begin{tabular}{|c|c|c|c|c|c|}
\hline \multicolumn{6}{|c|}{ First Dose } \\
\hline Polymorphism & $t_{1 / 2}$ & CL & $\mathbf{V}_{\mathrm{d}}$ & $\mathrm{C}_{\max }$ & $\mathrm{AUC}_{0-\mathrm{inf}}$ \\
\hline \multicolumn{6}{|l|}{ GSTA1 } \\
\hline${ }^{*} A{ }^{*} A(n=67)$ & $134.34 \pm 35.71^{\mathrm{T}}$ & $124.23 \pm 78.33$ * & $23,434.0 \pm 14,292.0$ & $3675.5 \pm 949.4^{\mathrm{T}}$ & $4177.1 \pm 1557.9^{\mathrm{T}}$ \\
\hline${ }^{*} A /{ }^{*} B(n=19)$ & $161.86 \pm 42.61^{\mathrm{T}}$ & $94.01 \pm 47.40$ * & $21,896.3 \pm 11,570.5$ & $4232.6 \pm 581.9^{\mathrm{T}}$ & $5310.6 \pm 1347.1^{\mathrm{T}}$ \\
\hline${ }^{*} B /{ }^{*} B(n=6)$ & $154.99 \pm 19.96^{\mathrm{T}}$ & $72.05 \pm 37.36^{*}$ & $16,266.7 \pm 9879.6$ & $4231.7 \pm 605.9^{\mathrm{T}}$ & $5296.4 \pm 968.6^{\mathrm{T}}$ \\
\hline \multicolumn{6}{|l|}{ GSTM1 } \\
\hline Deletion $(n=63)$ & $142.13 \pm 42.09$ & $119.75 \pm 65.23$ & $23,703.8 \pm 12,622.1$ & $3787.1 \pm 849.8$ & $4476.1 \pm 1698.7$ \\
\hline $1 C N V(n=26)$ & $141.27 \pm 27.75$ & $105.37 \pm 90.54$ & $20,971.9 \pm 16,022.6$ & $3896.9 \pm 1048.9$ & $4471.6 \pm 1250.5$ \\
\hline 2 or $3 C N V(n=3)$ & $126.16 \pm 26.63$ & $85.90 \pm 34.80$ & $15,033.3 \pm 5533.8$ & $4053.3 \pm 447.7$ & $4743.6 \pm 1146.0$ \\
\hline \multicolumn{6}{|l|}{ GSTP1 } \\
\hline$A / A(n=55)$ & $142.92 \pm 36.82$ & $115.71 \pm 77.39$ & $23,020.2 \pm 14,464$ & $3848.5 \pm 956.7$ & $4504.8 \pm 1654.8$ \\
\hline$A / G(n=35)$ & $139.91 \pm 41.03$ & $114.48 \pm 65.27$ & $22,491.7 \pm 12,157.1$ & $3793.4 \pm 832.6$ & $4460.9 \pm 1463.5$ \\
\hline$G / G(n=2)$ & $124.21 \pm 0.93$ & $85.20 \pm 85.98$ & $15,195 \pm 15,280.6$ & $3815 \pm 49.5$ & $4324.5 \pm 201.9$ \\
\hline \multicolumn{6}{|c|}{ Second Dose } \\
\hline Polymorphism & $t_{1 / 2}$ & CL & $\mathbf{V}_{\mathrm{d}}$ & $\mathrm{C}_{\max }$ & $\mathrm{AUC}_{0-\mathrm{inf}}$ \\
\hline \multicolumn{6}{|l|}{ GSTA1 } \\
\hline${ }^{*} A /{ }^{*} A(n=64)$ & $129.81 \pm 27.29^{\mathrm{T}}$ & $119.31 \pm 70.74$ & $22,007.0 \pm 12,898.1$ & $3825.5 \pm 968.6$ & $4165.1 \pm 1005.7$ \\
\hline${ }^{*} A{ }^{*} B(n=16)$ & $156.09 \pm 52.20^{\mathrm{F}}$ & $97.29 \pm 59.73$ & $21,496.3 \pm 12,524.5$ & $3679.4 \pm 1290.5$ & $4265.8 \pm 998.4$ \\
\hline${ }^{*} B /{ }^{*} B(n=6)$ & $142.65 \pm 17.61^{\mathrm{T}}$ & $75.85 \pm 38.68$ & $15,775 \pm 8377.1$ & $3070 \pm 446.1$ & $3646.5 \pm 257.7$ \\
\hline \multicolumn{6}{|l|}{ GSTM1 } \\
\hline Deletion $(n=60)$ & $137.17 \pm 38.34$ & $117.83 \pm 66.28$ & $22,707.5 \pm 12,469.3$ & $3781 \pm 1090.0$ & $4186.4 \pm 1003.3$ \\
\hline $1 \mathrm{CNV}(n=23)$ & $129.50 \pm 20.51$ & $101.40 \pm 74.80$ & $18,743.0 \pm 13,203.6$ & $3715.2 \pm 883.8$ & $4088.3 \pm 966.9$ \\
\hline 2 or $3 C N V(n=3)$ & $150.70 \pm 20.11$ & $81.83 \pm 25.72$ & $17,833.3 \pm 6560.7$ & $3270 \pm 350$ & $3827.8 \pm 392.1$ \\
\hline \multicolumn{6}{|l|}{ GSTP1 } \\
\hline$A / A(n=52)$ & $134.27 \pm 25.37$ & $116.27 \pm 73.34$ & $21,873.6 \pm 12,824.2$ & $3643.3 \pm 751.2$ & $4053.0 \pm 808.3$ \\
\hline$A / G(n=32)$ & $138.65 \pm 45.70$ & $106.94 \pm 58.18$ & $21,238.8 \pm 12,294.6$ & $3807.8 \pm 1213.3$ & $4260.7 \pm 1158.8$ \\
\hline$G / G(n=2)$ & $121.12 \pm 10.97$ & $89.95 \pm 94.82$ & $14,980 \pm 15,160.3$ & $5410 \pm 2771.9$ & $4800.1 \pm 2017.4$ \\
\hline \multicolumn{6}{|c|}{$\begin{array}{l}{ }^{*} \text { Statistically significant according to two-tailed } t \text {-test analysis }(p<0.05 \text { ) between group } 1 \text { homozygous wildtype } \\
\text { (or deletion), group } 2 \text { heterozygous (or } 1 \mathrm{CNV}) \text {, and group } 3 \text { homozygous variant (or } 2 \text { or } 3 \mathrm{CNV} \text { ); }{ }^{\mp} \text { Statistically } \\
\text { significant according to one-way ANOVA }(p<0.05) \text { between group } 1 \text { homozygous wildtype (or deletion), group } \\
2 \text { heterozygous (or } 1 \mathrm{CNV} \text { ), and group } 3 \text { homozygous variant (or } 2 \text { or } 3 \mathrm{CNV} \text { ). The units of PK parameters } \\
\mathrm{t}_{1 / 2}, \mathrm{~min} ; \mathrm{CL}, \mathrm{mL} / \mathrm{min} ; \mathrm{Vd}, \mathrm{mL} ; \mathrm{C}_{\max }, \mathrm{ng} / \mathrm{mL} ; \mathrm{AUC}_{0-\mathrm{inf}}, \mu \mathrm{M} / \mathrm{min} \text {. }\end{array}$} \\
\hline
\end{tabular}


Before dose adjustment, the percentage of patients higher than, within, and lower than the target range was $11 \%, 59 \%$ and $30 \%$, respectively (Figure 1E). After dose adjustment, these numbers were $5 \%, 74 \%$ and $21 \%$, respectively (Figure $1 \mathrm{~J}$ ). The mean AUCs of homozygous wild-type, heterozygous variant, and homozygous variant of GSTA1 were 4177,5310 , and $5296 \mu \mathrm{M} / \mathrm{min}$, respectively (Figure 1E). The carriers of variant GSTA1*B exhibited an augmentation in AUC of around $27.1 \%(p=0.0071)$.

3.5. Multivariate Regression Analysis between PK of Bu and Three Independent Variables: BSA, GSTA1 and Gender

The multivariable regression analysis in Table S2 illustrates that the PK of Bu was impacted by BSA, GSTA1 polymorphism and gender. Through each step of inclusion of the new variable, the new model was compared with the previous one, whereby the new one showed a better performance in terms of fitting (F statistic and $\triangle \mathrm{F}$ with $p<0.05$ ).

In the group of all patients, BSA and GSTA1 polymorphism had impacts on $t_{1 / 2}$ and $\mathrm{CL}$, whereas BSA, GSTA1 polymorphism and gender had impacts on Vd. After stratification of patients at the age of 6, BSA and GSTA1 polymorphism became the first and second most important factors for those below the threshold, whereas GSTA1 polymorphism was the most important factor for those above the threshold.
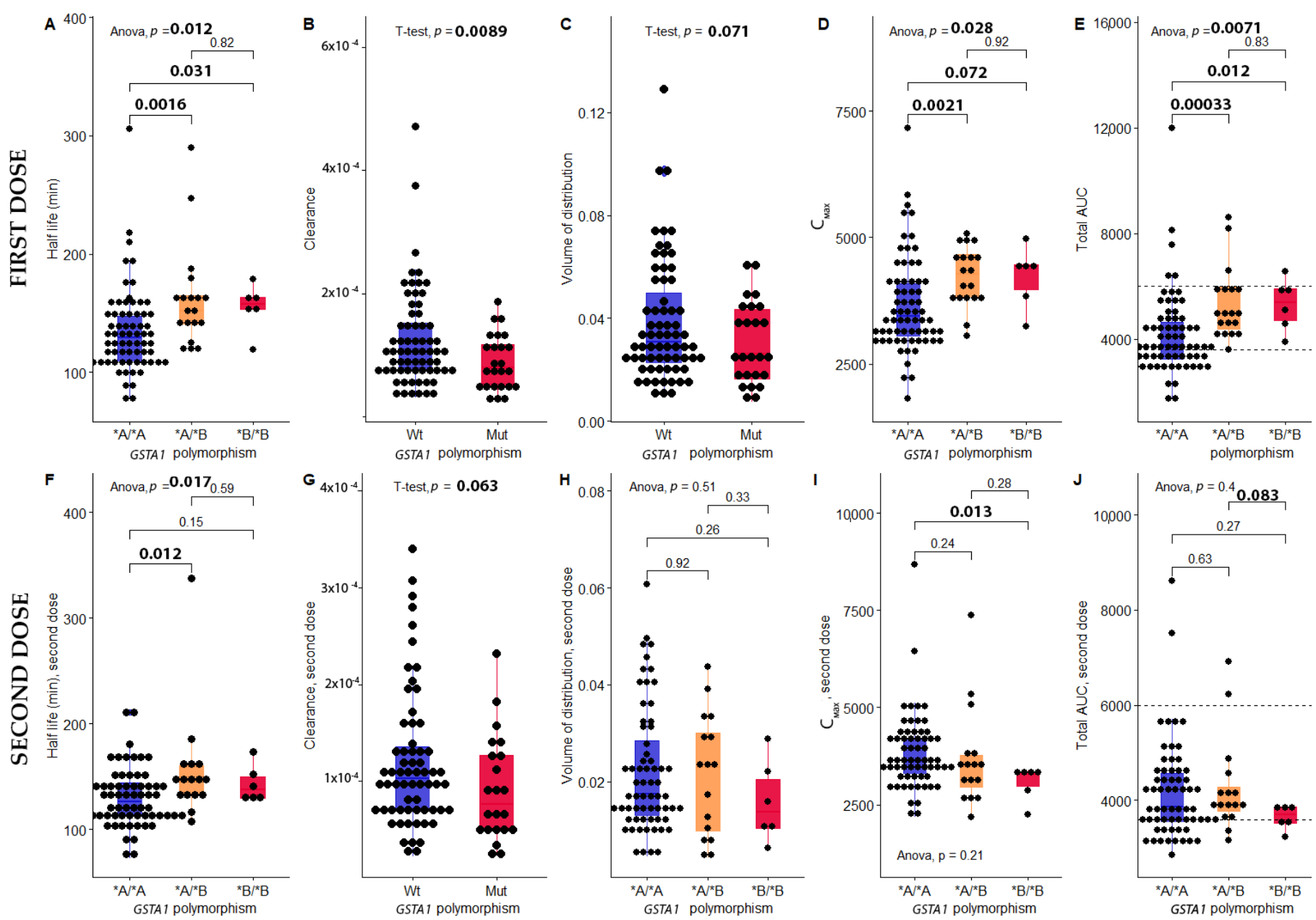

Figure 1. The impact of GSTA1 polymorphism on each PK parameter of Busulfan at fist dose (A): Half-life; (B): Clearance; (C): Volume of distribution; (D): $\mathrm{C}_{\max }$ (E): Total AUC, and at second dose: (F): Half-life; (G): Clearance; (H): Volume of distribution; (I): $\mathrm{C}_{\max }$; (J): Total AUC. GSTA1: Glutathione-S-tranferase; AUC: Area Under the Curve; Wt: Wild-type; Mut: Mutant; ${ }^{*}$ A ${ }^{*} \mathrm{~A}$ : Homozygous wild-type; ${ }^{*} A /{ }^{*} B$ : Heterozygous; ${ }^{*} B /{ }^{*} B$ : Homozygous mutant. Anova: Compare more than 2 groups, 2 tails $t$-test: Compare 2 groups. Statistically significant threshold: 0.05 . 


\section{Discussion}

Among all pediatric Asian populations, this study is the first to successfully detect the genetic impacts on the PK disposition of busulfan. More specifically, we targeted the Thai pediatric population expected to receive HSCT. The genetic impacts of this specific population remained unknown until today because (1) children's metabolism varies widely across individuals, and (2) there is a lower allele frequency in Asians than in Caucasians [10], with the exception of Israelis. However, this genetic culprit in Asians is still prevalent enough to make this specific population vulnerable. This study provides evidence that the GSTA1 polymorphism has an impact on the PK of busulfan.

In our cohort, phenytoin and ciprofloxacin were administered to all patients. Therefore, the potential confounding effects of drug-drug interactions between phenytoin [28,29] or ciprofloxacin and busulfan were minimized. The distributions of allele frequencies differ across ethnicities. Regarding GSTA1, the current analysis reported the frequency of $G S T A 1^{*} B$ at around $16.9 \%$ which is $2-3$ times lower than reported in Caucasians [19,30-34], but similar to other Asian populations, such as the Chinese [21,35,36], Koreans [37], and Japanese [22,38]. Two SNPs detected in GSTA1, G-52A (rs3957356) and C69T (rs3957357), are in a full linkage disequilibrium, in line with other populations, such as Caucasians [19,34], Koreans [30] and Chinese [21]. The polymorphisms of GSTM1 included deletions and 1-3 CNVs in our cohort. It was infeasible to test for the Hardy-Weinberg equilibrium of GSTM1 using real-time PCR genotyping. A genotyping method with higher resolution such as sequencing should be adopted to identify the exact positions of each GSTM1 sequence on its homologous chromosomes. In this study, GSTP1*G had a frequency of $21.2 \%$, which is consistent with other Asian populations [11,21], but lower than observed in Caucasians ( 37-45\%) [19,32,33].

The adjustment of individual doses hindered the detection of genetic impacts in second doses with respect to first doses. Hence, in the first dose, the genetic impacts of GSTA1 were related to half-life, $\mathrm{C}_{\max }, \mathrm{AUC}, \mathrm{CL}$ and $\mathrm{Vd}$, whereas, in the second doses, only half-life and CL registered impacts with $p$-values of 0.017 and 0.063 , respectively. The carriers of the variant allele $G S T A 1^{*} B$ had a lower $C L$, which in turn reduced the elimination of busulfan; this was associated with increased AUC. In contrast to GSTA1, we did not detect any statistical significance in GSTM1 and GSTP1. This observation can be explained by the quantity of GSTM1 and GSTP1 enzymes in liver cells (equal to $46 \%$ and $18 \%$ of GSTA1, respectively) [17]. Nishikawa et al. [22] investigated Japanese pediatric patients but obtained negative results due to the small sample size, which reduced the power of detection. In Israeli pediatric patients, Elhasid et al. [23] successfully proved the impact of GSTA1 on the PK of busulfan. Even though Israel is geographically considered to be a part of Asia, the allele frequency of $G S T A 1^{*} B$ in Israelis is $55 \%$, which is similar to some Caucasian populations $[15,19,39]$, and far higher than in other Asian populations [10,22]. The reason for the similarity between Israelis and Caucasians can be explained by geography and history. Indeed, in Caucasian pediatric populations, many authors found an effect of GSTA1. Ansari et al. [19] conducted a meticulous study using a multicenter cohort and proved the associations of GSTA1 and GSTM1 not only with CL and AUC, but also with clinical outcomes such as sinusoidal obstruction syndrome (SOS), graft-versus-host disease (GvHD) and hemorrhagic cystitis (HC). Ten Brink et al. [15] provided evidence of GSTA1 and CYP39A1 polymorphisms as influencing factors of busulfan clearance. In contrast to GSTA1, a plausible explanation for the role of CYP39A1 in busulfan metabolism is still lacking. More clarification is needed to establish a thorough understanding of the role played by CYP39A1. In adults, many authors confirmed the impacts of GSTA1 in Asians and Caucasians (Supplementary Table S1), such as Kim et al. in Koreans [30], Terakura et al. in Japanese [14], and Michaud et al. in Canadians [40].

Even though the allele frequency of $G S T A 1^{*} B$ in Asians is far lower than in Caucasians [10], this study suggests the incorporation of the GSTA1 polymorphism into the dosing regimen of busulfan in pediatric Asians. With an allele frequency of $\sim 17 \%$, carriers of the GSTA1*B allele had an AUC augmentation of around $27.1 \%$. Therefore, the 
adjusted dosages should be decreased accordingly in patients carrying GSTA1*B variant. Overexposure to busulfan may lead to GvHD, SOS, or lower overall survival [5,6]. Busulfan treatment in pediatric Asians can be more personalized if pharmacogenetic testing of GSTA1 is implemented to adjust the doses accordingly.

The effect of nongenetic factors is given special attention in pediatrics. In our study, an involvement of BSA and gender was found. Table S2 shows that BSA was important in the group $<6$ years old. In contrast, BSA was not statistically significant in the older group, whereas GSTA1 polymorphism emerged as important. The inconsistency between the two groups can be explained by the maturation of liver enzymes along with the growth of BSA [41]. The impact of gender on activity of the microsomal GST enzyme has been suggested in mice [42] and humans [43]. This impact can be explained by the participation of testosterone/estrogen [44-46], in the expression of the microsomal GST enzyme. The impacts of nongenetic factors were also noted in pediatric Caucasians. Ansari et al. [19] described the effects of nongenetic factors age and gender, whereas Ten Brink et al. [15] found an effect of age but not gender. Interestingly, Nava et al. [39] defined the maturation level of children's enzymes using another parameter, Fmat. This parameter was shown to be associated with the PK of Bu. Even though many nongenetic factors have been reported, most of these factors represent the maturation of liver enzymes.

This research had some limitations, necessitating future efforts to clarify several issues. First, this study classified patients into carriers and noncarriers. However, upon increasing the sample size, patients can be further classified into subgroups, as suggested by Ansari et al. [19], taking into account more genetic variants to achieve more personalized treatment. Second, this study included children $<6$ years old. These infants and toddlers are more fragile and pharmacokinetically unpredictable from a clinical point of view. Thus, more analyses should be performed in these age groups. Third, the association between GST polymorphism and clinical outcomes was not assessed in the current study, which could produce more persuasive evidence of the genetic impacts on Bu response. Lastly, the role of drug-drug interactions should be taken into consideration in further studies, such as between fludarabine and busulfan $[47,48]$, between cyclophosphamide and busulfan $[49,50]$, between phenytoin and busulfan [28,29], and between ciprofloxacin and busulfan [51].

In conclusion, GSTA1 polymorphisms were significantly associated with variations in the PK profile of busulfan and could be considered potential pharmacogenetic factors when personalizing busulfan treatment in pediatric Asians. The findings of this study may accelerate the implementation of precision medicine when administering busulfan in clinical practice. GSTM1 and GSTP1 polymorphisms were not found to be statistically significant factors in this study; however, more research is needed to properly understand their role in pediatric Asians receiving busulfan.

Supplementary Materials: The following are available online at https:/ / www.mdpi.com/article/ 10.3390/pharmaceutics14020401/s1: Table S1. Review of 18 articles regarding polymorphisms of the GST family and the PK of Busulfan [52-55]; Table S2. Multivariate regression analysis between PK of $\mathrm{Bu}$ and three independent variables: BSA, GSTA1, and gender.

Author Contributions: Conceptualization, C.S., A.P. and S.H.; methodology, C.S., M.B. and A.-H.N.; software, R.S. and N.N.; formal analysis, N.J., J.R. and A.-H.N.; investigation, A.-H.N.; resources, S.P. (Santirhat Prommas) and S.P. (Samart Pakakasama); data curation, R.S., J.R. and U.A.; writingoriginal draft preparation, A.-H.N.; writing-review and editing, M.B. and C.S.; visualization, A.-H.N.; supervision, C.S.; project administration, S.H. and C.S.; funding acquisition, C.S. All authors have read and agreed to the published version of the manuscript.

Funding: This research was supported by the internal funding obtained from (1) Mahidol University International Postdoctoral Fellowship, Mahidol University, (2) Faculty of Medicine, Ramathibodi Hospital, Mahidol University, and (3) Franco-Thai Scholarship Program. The authors thank the staff in the Pharmacogenomic and Personalized Medicine Department of Ramathibodi Hospital. 
Institutional Review Board Statement: The study was conducted according to the guidelines of the Declaration of Helsinki and approved by the Institutional Review Board (or Ethics Committee) of Ramathibodi hospital, Mahidol university (protocol code ID 04-61-37 and date of approval 12 June 2018).

Informed Consent Statement: Informed consent was obtained from all subjects involved in the study.

Data Availability Statement: The data that support the findings of this study are available from the corresponding author upon reasonable request.

Acknowledgments: The authors thank the patients and their parents who took part in this study.

Conflicts of Interest: The authors declare no conflict of interest.

\section{References}

1. Hatzimichael, E.; Tuthill, M. Hematopoietic stem cell transplantation. Stem Cells Cloning 2010, 3, 105-117. [CrossRef]

2. Kebriaei, P.; Anasetti, C.; Zhang, M.-J.; Wang, H.-L.; Aldoss, I.; de Lima, M.; Khoury, H.J.; Sandmaier, B.M.; Horowitz, M.M.; Artz, A.; et al. Intravenous Busulfan Compared with Total Body Irradiation Pretransplant Conditioning for Adults with Acute Lymphoblastic Leukemia. Biol. Blood Marrow Transplant. 2018, 24, 726-733. [CrossRef]

3. Champlin, R.E. Busulfan or TBI: Answer to an age-old question. Blood 2013, 122, 3856-3857. [CrossRef] [PubMed]

4. Bredeson, C.; LeRademacher, J.; Kato, K.; Dipersio, J.F.; Agura, E.; Devine, S.M.; Appelbaum, F.R.; Tomblyn, M.R.; Laport, G.G.; Zhu, X.; et al. Prospective cohort study comparing intravenous busulfan to total body irradiation in hematopoietic cell transplantation. Blood 2013, 122, 3871-3878. [CrossRef]

5. $\quad$ Bartelink, I.H.; Bredius, R.G.; Belitser, S.V.; Suttorp, M.M.; Bierings, M.; Knibbe, C.A.; Egeler, M.; Lankester, A.C.; Egberts, A.C.; Zwaveling, J. Association between busulfan exposure and outcome in children receiving intravenous busulfan before hematologic stem cell transplantation. Biol. Blood Marrow Transplant. 2009, 15, 231-241. [CrossRef] [PubMed]

6. Geddes, M.; Kangarloo, S.B.; Naveed, F.; Quinlan, D.; Chaudhry, M.A.; Stewart, D.; Savoie, M.L.; Bahlis, N.J.; Brown, C.; Storek, J. High busulfan exposure is associated with worse outcomes in a daily iv busulfan and fludarabine allogeneic transplant regimen. Biol. Blood Marrow Transplant. 2008, 14, 220-228. [CrossRef] [PubMed]

7. $\quad$ Feng, X.; Wu, Y.; Zhang, J.; Li, J.; Zhu, G.; Fan, D.; Yang, C.; Zhao, L. Busulfan systemic exposure and its relationship with efficacy and safety in hematopoietic stem cell transplantation in children: A meta-analysis. BMC Pediatrics 2020, 20, 176. [CrossRef]

8. Corbacioglu, S.; Carreras, E.; Ansari, M.; Balduzzi, A.; Cesaro, S.; Dalle, J.-H.; Dignan, F.; Gibson, B.; Guengoer, T.; Gruhn, B. Diagnosis and severity criteria for sinusoidal obstruction syndrome/veno-occlusive disease in pediatric patients: A new classification from the European society for blood and marrow transplantation. Bone Marrow Transplant. 2018, 53, 138-145. [CrossRef] [PubMed]

9. Bonifazi, F.; Barbato, F.; Ravaioli, F.; Sessa, M.; Defrancesco, I.; Arpinati, M.; Cavo, M.; Colecchia, A. Diagnosis and treatment of VOD/SOS after allogeneic hematopoietic stem cell transplantation. Front. Immunol. 2020, 11, 489. [CrossRef] [PubMed]

10. Sun, Y.; Huang, J.; Hao, C.; Li, Z.; Liang, W.; Zhang, W.; Chen, B.; Yang, W.; Hu, J. Population pharmacokinetic analysis of intravenous busulfan: GSTA1 genotype is not a predictive factor of initial dose in Chinese adult patients undergoing hematopoietic stem cell transplantation. Cancer Chemother. Pharmacol. 2020, 85, 293-308. [CrossRef] [PubMed]

11. Wongpratate, M.; Phuthong, S.; Natphopsuk, S.; Ishida, T. Genetic polymorphism of glutathione S-transferase and cervical cancer susceptibility in Northeastern Thailand. Asian Pac. J. Cancer Biol. 2020, 5, 35-41.

12. Myers, A.L.; Kawedia, J.D.; Champlin, R.E.; Kramer, M.A.; Nieto, Y.; Ghose, R.; Andersson, B.S. Clarifying busulfan metabolism and drug interactions to support new therapeutic drug monitoring strategies: A comprehensive review. Expert Opin. Drug Metab. Toxicol. 2017, 13, 901-923. [CrossRef] [PubMed]

13. Uppugunduri, C.R.S.; Rezgui, M.A.; Diaz, P.H.; Tyagi, A.K.; Rousseau, J.; Daali, Y.; Duval, M.; Bittencourt, H.; Krajinovic, M.; Ansari, M. The association of cytochrome P450 genetic polymorphisms with sulfolane formation and the efficacy of a busulfan-based conditioning regimen in pediatric patients undergoing hematopoietic stem cell transplantation. Pharm. J. 2014, 14, 263-271. [CrossRef] [PubMed]

14. Terakura, S.; Onizuka, M.; Fukumoto, M.; Kuwatsuka, Y.; Kohno, A.; Ozawa, Y.; Miyamura, K.; Inagaki, Y.; Sawa, M.; Atsuta, Y. Analysis of glutathione S-transferase and cytochrome P450 gene polymorphism in recipients of dose-adjusted busulfan-cyclophosphamide conditioning. Int. J. Hematol. 2020, 111, 84-92. [CrossRef]

15. Ten Brink, M.H.; Van Bavel, T.; Swen, J.J.; Straaten, T.v.d.; Bredius, R.G.; Lankester, A.C.; Zwaveling, J.; Guchelaar, H.-J. Effect of genetic variants GSTA1 and CYP39A1 and age on busulfan clearance in pediatric patients undergoing hematopoietic stem cell transplantation. Pharmacogenomics 2013, 14, 1683-1690. [CrossRef]

16. Strange, R.C.; Spiteri, M.A.; Ramachandran, S.; Fryer, A.A. Glutathione-S-transferase family of enzymes. Mutat. Res. /Fundam. Mol. Mech. Mutagenesis 2001, 482, 21-26. [CrossRef]

17. Czerwinski, M.; Gibbs, J.P.; Slattery, J.T. Busulfan conjugation by glutathione S-transferases alpha, mu, and pi. Drug Metab. Dispos. 1996, 24, 1015-1019.

18. Morel, F.; Rauch, C.; Coles, B.; Le Ferrec, E.; Guillouzo, A. The human glutathione transferase alpha locus: Genomic organization of the gene cluster and functional characterization of the genetic polymorphism in the hGSTA1 promoter. Pharm. Genom. 2002, 12, 277-286. 
19. Ansari, M.; Curtis, P.H.-D.; Uppugunduri, C.R.S.; Rezgui, M.A.; Nava, T.; Mlakar, V.; Lesne, L.; Théoret, Y.; Chalandon, Y.; Dupuis, L.L. GSTA1 diplotypes affect busulfan clearance and toxicity in children undergoing allogeneic hematopoietic stem cell transplantation: A multicenter study. Oncotarget 2017, 8, 90852-90867. [CrossRef]

20. Johnson, L.A.; Orchard, P.J.; Baker, K.S.; Brundage, R.; Cao, Q.; Wang, X.; Langer, E.; Maasah, S.F.E.; Ross, J.A.; Remmel, R. Glutathione S-transferase A1 genetic variants reduce busulfan clearance in children undergoing hematopoietic cell transplantation. J. Clin. Pharmacol. 2008, 48, 1052-1062. [CrossRef]

21. Yin, J.; Xiao, Y.; Zheng, H.; Zhang, Y. Once-daily iv BU-based conditioning regimen before allogeneic hematopoietic SCT: A study of influence of GST gene polymorphisms on BU pharmacokinetics and clinical outcomes in Chinese patients. Bone Marrow Transplant. 2015, 50, 696-705. [CrossRef]

22. Nishikawa, T.; Yamaguchi, H.; Ikawa, K.; Nakayama, K.; Higashi, E.; Miyahara, E.; Abematsu, T.; Nakagawa, S.; Kodama, Y.; Tanabe, T. Influence of GST polymorphisms on busulfan pharmacokinetics in Japanese children. Pediatrics Int. 2019, 61, 558-565. [CrossRef]

23. Elhasid, R.; Krivoy, N.; Rowe, J.M.; Sprecher, E.; Adler, L.; Elkin, H.; Efrati, E. Influence of glutathione S-transferase A1, P1, M1, T1 polymorphisms on oral busulfan pharmacokinetics in children with congenital hemoglobinopathies undergoing hematopoietic stem cell transplantation. Pediatric Blood Cancer 2010, 55, 1172-1179. [CrossRef]

24. Ansari, M.; Lauzon-Joset, J.; Vachon, M.; Duval, M.; Theoret, Y.; Champagne, M.; Krajinovic, M. Influence of GST gene polymorphisms on busulfan pharmacokinetics in children. Bone Marrow Transplant. 2010, 45, 261-267. [CrossRef]

25. Jahed, F.S.; Hamidi, S.; Ghaffary, S.; Nejati, B. Dispersive micro solid phase extraction of busulfan from plasma samples using novel mesoporous sorbent prior to determination by HPLC-MS/MS. J. Chromatogr. B 2020, 1145, 122091. [CrossRef]

26. Xu, S.-j.; Wang, Y.-p.; Roe, B.; Pearson, W.R. Characterization of the Human Class Mu Glutathione S-Transferase Gene Cluster and the GSTM1Deletion. J. Biol. Chem. 1998, 273, 3517-3527. [CrossRef]

27. Chen, B.; Cole, J.W.; Grond-Ginsbach, C. Departure from Hardy Weinberg equilibrium and genotyping error. Front. Genet. 2017, 8, 167. [CrossRef]

28. Hassan, M.; Öberg, G.; Björkholm, M.; Wallin, I.; Lindgren, M. Influence of prophylactic anticonvulsant therapy on high-dose busulphan kinetics. Cancer Chemother. Pharmacol. 1993, 33, 181-186. [CrossRef]

29. Nguyen, L.; Leger, F.; Lennon, S.; Puozzo, C. Intravenous busulfan in adults prior to haematopoietic stem cell transplantation: A population pharmacokinetic study. Cancer Chemother. Pharmacol. 2006, 57, 191-198. [CrossRef]

30. Kim, S.-D.; Lee, J.-H.; Hur, E.-H.; Lee, J.-H.; Kim, D.-Y.; Lim, S.-N.; Choi, Y.; Lim, H.-S.; Bae, K.-S.; Noh, G.-J. Influence of GST gene polymorphisms on the clearance of intravenous busulfan in adult patients undergoing hematopoietic cell transplantation. Biol. Blood Marrow Transplant. 2011, 17, 1222-1230. [CrossRef]

31. Gaziev, J.; Nguyen, L.; Puozzo, C.; Mozzi, A.F.; Casella, M.; Perrone Donnorso, M.; Gravina, P.; Sodani, P.; Marziali, M.; Isgro, A Novel pharmacokinetic behavior of intravenous busulfan in children with thalassemia undergoing hematopoietic stem cell transplantation: A prospective evaluation of pharmacokinetic and pharmacodynamic profile with therapeutic drug monitoring. Blood J. Am. Soc. Hematol. 2010, 115, 4597-4604. [CrossRef] [PubMed]

32. Córdoba, E.E.; Abba, M.C.; Lacunza, E.; Fernánde, E.; Güerci, A.M. Polymorphic variants in oxidative stress genes and acute toxicity in breast cancer patients receiving radiotherapy. Cancer Res. Treat. Off. J. Korean Cancer Assoc. 2016, 48, 948-954. [CrossRef] [PubMed]

33. Bremer, S.; Fløisand, Y.; Brinch, L.; Gedde-Dahl, T.; Bergan, S. Glutathione transferase gene variants influence busulfan pharmacokinetics and outcome after myeloablative conditioning. Ther. Drug Monit. 2015, 37, 493-500. [CrossRef] [PubMed]

34. Abbasi, N.; Vadnais, B.; Knutson, J.A.; Blough, D.K.; Kelly, E.J.; O’Donnell, P.V.; Deeg, H.J.; Pawlikowski, M.A.; Ho, R.J.Y.; McCune, J.S. Pharmacogenetics of intravenous and oral busulfan in hematopoietic cell transplant recipients. J. Clin. Pharmacol. 2011, 51, 1429-1438. [CrossRef]

35. Zong, C.; Sha, Y.; Xiang, H.; Wang, J.; Chen, D.; Liu, J.; Wang, B.; Cao, Y. Glutathione S-transferase A1 polymorphism and the risk of recurrent spontaneous abortion in Chinese Han population. J. Assist. Reprod. Genet. 2014, 31, 379-382. [CrossRef]

36. Ping, J.; Wang, H.; Huang, M.; Liu, Z.-s. Genetic analysis of glutathione S-transferase A1 polymorphism in the Chinese population and the influence of genotype on enzymatic properties. Toxicol. Sci. 2006, 89, 438-443. [CrossRef]

37. Choi, B.; Kim, M.G.; Han, N.; Kim, T.; Ji, E.; Park, S.; Kim, I.-W.; Oh, J.M. Population pharmacokinetics and pharmacodynamics of busulfan with GSTA1 polymorphisms in patients undergoing allogeneic hematopoietic stem cell transplantation. Pharmacogenomics 2015, 16, 1585-1594. [CrossRef]

38. Matsuno, K.; Kubota, T.; Matsukura, Y.; Ishikawa, H.; Iga, T. Genetic analysis of glutathione S-transferase A1 and T1 polymorphisms in a Japanese population. Clin. Chem. Lab. Med. 2004, 42, 560-562. [CrossRef]

39. Nava, T.; Kassir, N.; Rezgui, M.A.; Uppugunduri, C.R.S.; Huezo-Diaz Curtis, P.; Duval, M.; Théoret, Y.; Daudt, L.E.; Litalien, C.; Ansari, M. Incorporation of GSTA1 genetic variations into a population pharmacokinetic model for IV busulfan in paediatric hematopoietic stem cell transplantation. Br. J. Clin. Pharmacol. 2018, 84, 1494-1504. [CrossRef]

40. Michaud, V.; Tran, M.; Pronovost, B.; Bouchard, P.; Bilodeau, S.; Alain, K.; Vadnais, B.; Franco, M.; Bélanger, F.; Turgeon, J. Impact of GSTA1 polymorphisms on busulfan oral clearance in adult patients undergoing hematopoietic stem cell transplantation. Pharmaceutics 2019, 11, 440. [CrossRef]

41. Preedy, V.R. Handbook of Anthropometry: Physical Measures of Human form in Health and Disease; Springer Science \& Business Media: Berlin, Germany, 2012. 
42. Mitchell, A.E.; Burns, S.A.; Rudolf, J.L. Isozyme-and gender-specific induction of glutathione S-transferases by flavonoids. Arch Toxicol. 2007, 81, 777-784. [CrossRef] [PubMed]

43. Miyagi, S.J.; Brown, I.W.; Chock, J.M.; Collier, A.C. Developmental changes in hepatic antioxidant capacity are age-and sexdependent. J. Pharmacol. Sci. 2009, 111, 440-445. [CrossRef] [PubMed]

44. Hatayama, I.; Satoh, K.; Sato, K. Developmental and hormonal regulation of the major form of hepatic glutathione S-transferase in male mice. Biochem. Biophys. Res. Commun. 1986, 140, 581-588. [CrossRef]

45. Staffas, L.; Ellis, E.M.; Hayes, J.D.; Lundgren, B.; Depierre, J.W.; Mankowitz, L. Growth hormone-and testosterone-dependent regulation of glutathione transferase subunit A5 in rat liver. Biochem. J. 1998, 332, 763-768. [CrossRef] [PubMed]

46. Ansell, P.; Espinosa-Nicholas, C.; Curran, E.; Judy, B.; Philips, B.; Hannink, M.; Lubahn, D. In vitro and in vivo regulation of antioxidant response element-dependent gene expression by estrogens. Endocrinology 2004, 145, 311-317. [CrossRef] [PubMed]

47. de Castro, F.A.; Lanchote, V.L.; Voltarelli, J.C.; Colturato, V.A.R.; Simões, B.P. Influence of fludarabine on the pharmacokinetics of oral busulfan during pretransplant conditioning for hematopoietic stem cell transplantation. J. Clin. Pharmacol. 2013, 53, 1205-1211. [CrossRef]

48. Yeh, R.F.; Pawlikowski, M.A.; Blough, D.K.; McDonald, G.B.; O’Donnell, P.V.; Rezvani, A.; Deeg, H.J.; McCune, J.S. Accurate targeting of daily intravenous busulfan with 8-hour blood sampling in hospitalized adult hematopoietic cell transplant recipients. Biol. Blood Marrow Transplant. 2012, 18, 265-272. [CrossRef]

49. Rezvani, A.R.; McCune, J.S.; Storer, B.E.; Batchelder, A.; Kida, A.; Deeg, H.J.; McDonald, G.B. Cyclophosphamide followed by intravenous targeted busulfan for allogeneic hematopoietic cell transplantation: Pharmacokinetics and clinical outcomes. Biol. Blood Marrow Transplant. 2013, 19, 1033-1039. [CrossRef]

50. McCune, J.S.; Batchelder, A.; Deeg, H.J.; Gooley, T.; Cole, S.; Phillips, B.; Schoch, H.G.; McDonald, G.B. Cyclophosphamide following targeted oral busulfan as conditioning for hematopoietic cell transplantation: Pharmacokinetics, liver toxicity, and mortality. Biol. Blood Marrow Transplant. 2007, 13, 853-862. [CrossRef]

51. Bensinger, W.I.; Buckner, C.D.; Lilleby, K.; Holmberg, L.; Storb, R.; Slattery, J.T. Dose escalation of busulfan with pentoxifylline and ciprofloxacin in patients with breast cancer undergoing autologous transplants. Oncology 2004, 67, 368-375. [CrossRef]

52. Nava, T.; Rezgui, M.A.; Uppugunduri, C.R.; Curtis, P.H.-D.; Théoret, Y.; Duval, M.; Daudt, L.E.; Ansari, M.; Krajinovic, M.; Bittencourt, H. GSTA1 genetic variants and conditioning regimen: Missing key factors in dosing guidelines of busulfan in pediatric hematopoietic stem cell transplantation. Biol. Blood Marrow Transplant. 2017, 23, 1918-1924. [CrossRef] [PubMed]

53. Kusama, M.; Kubota, T.; Matsukura, Y.; Matsuno, K.; Ogawa, S.; Kanda, Y.; Iga, T. Influence of glutathione S-transferase A1 polymorphism on the pharmacokinetics of busulfan. Clin. Chim. Acta 2006, 368, 93-98. [CrossRef] [PubMed]

54. Marloes, H.; Swen, J.J.; Böhringer, S.; Wessels, J.A.; van der Straaten, T.; Marijt, E.W.; Peter, A.; Zwaveling, J.; Guchelaar, H.-J. Exploratory analysis of 1936 SNPs in ADME genes for association with busulfan clearance in adult hematopoietic stem cell recipients. Pharm. Genom. 2013, 23, 675-683.

55. Ten Brink, M.; Wessels, J.; Den Hartigh, J.; Van Der Straaten, T.; Von Dem Borne, P.; Guchelaar, H.; Zwaveling, J. Effect of genetic polymorphisms in genes encoding GST isoenzymes on BU pharmacokinetics in adult patients undergoing hematopoietic SCT. Bone Marrow Transplant. 2012, 47, 190-195. [CrossRef] 